\title{
Social Versus Financial Performance of Microfinance: Bangladesh Perspective
}

\author{
Mohammad Aslam ${ }^{1}$, Senthil Kumar ${ }^{1} \&$ Shahryar Sorooshian ${ }^{2}$ \\ ${ }^{1}$ Faculty of Industrial Management, Universiti Malaysia Pahang, Pahang, Malaysia \\ ${ }^{2}$ Department of Business Administration, University of Gothenburg, Sweden \\ Correspondence: Mohammad Aslam, Universiti Malaysia Pahang, Pahang, Malaysia.
}

Received: September 30, 2019

Accepted: November 14, 2019

Online Published: November 30, 2019

doi:10.5430/rwe.v10n3p263

URL: https://doi.org/10.5430/rwe.v10n3p263

\begin{abstract}
Microfinance is a tool designed for poverty alleviation by providing financial services more specifically small credit to the poor household for income generating activities. One of the better ways to help poor people for poverty alleviation is through giving them financial services that cannot be done in traditional banking system. However, there is a big question whether it is possible to provide those services for a financial institution without being sustainable financially. How far it can go with free lunch that is depending on donors' fund. These two patterns place microfinance at the intersection. One may wonder whether the microfinance compromises a trade-off between serving the poor as social objective and attaining financial sustainability as financial objective. If microfinance institute wishes to get financial sustainability through profit maximization rather ignoring intended social objective of alleviating poverty, than it loses its momentum and becomes like other traditional financial institute. Fulfilling social objective with financial sustainability will be the optimum outcome of microfinance. Microfinance has been pioneered primarily in Bangladesh and later replicated in rest of the world. By this time, over 33 million of clients are being served with various financial and non-financial services by over 700 registered microfinance institute in Bangladesh. This study intent to measure the social outreach versus financial sustainability of microfinance institute in Bangladesh through panel data analysis. To do this, we have analyzed the relationship between financial performance and depth of outreach of top 20 microfinance institutes of Bangladesh from 2015 to 2017. Our results show that the relationship is positive or neutral in some cases. Therefore, microfinance in Bangladesh has been attaining both social and financial objectives and there appears no mission drift.
\end{abstract}

Keywords: microfinance, social outreach, financial sustainability, Panel Data Analysis

\section{Introduction}

Direct Credit Approach (Welfarist Approach) emphasizes on social performance. It recognizes microfinance as an effective instrument to fight against poverty and vulnerability. Ultimately, it progresses the welfare of the people living behind poverty. Besides micro credit and related services, microfinance provides non-financial services like education \& training together with technical assistance to borrowers for running their income generating activities. This welfare vision prevailed all through the 1980 decades. It emphases on forming commonality organizations like Non-Governmental Organization or Cooperative Societies which treat microfinance as a major instrument to reduce poverty of poorest (Hamed, 2004). The well-known instance of this approach is famous Grameen Bank. The other instance is the village banking system formulated by FINCA (Foundation of International Community Assistance) in Latin America and more lately in Asia and Africa. However, this welfare approach directed to high default with high transaction costs. It resulted in many microcredit program failures on the basis of subsidization meaning interest rates were even lower than market rates (Von Pischke, Adams, \& Donald, 1983; Yaron, 1994).

Financial Market Approach (Institutionalist Approach) emphasizing on financial performance put the microfinance within ambit of the market. It intends to set up financially sustainable microfinance institution being aware of resource constraints from donors and also wants to outreach the majority poor people (De Briey, 2005). Microfinance institute should reach financial sustainability through efficiency and productivity. As a result, they need to charge higher interest rate to make up all operational cost. Here, they compromise with serving the welfare of very poor to get them out of poverty. Rather, they start serving the clients close to poverty level with geographical concentration but involved in highly profitable and short cycled activities. For example, countries such as Bolivia, 
Peru etc. are offering to form particular regulated institution for microfinance. These special microfinance institutions get limited companies' status and moving away from NGO status. It clearly reveals the jurisdiction of maximization of profit rather than welfare (De Briey, 2005).

Microfinance should not take the traditional commercial approach of maximizing profit and ignore its main poverty alleviation objective. Attaining both social outreach and financial sustainability should be the optimum solution although quite challenging. This study intent to find out the approach of microfinance institutes in Bangladesh for attaining these two objectives. The rest portion of the work will be presented as follows. It gives the overview about institutionalist and welfarist approach including microfinance institute performance and measurement perspective. Thereafter, it presents the research methodology including measurement indicators, analysis and interpretation followed by summary and conclusion.

\section{Institutionalist and Welfarist Approach}

Institutionalist hold the view that the sustainability of microfinance institutions depends on profit maximization and welfarist emphasize on reaching out to maximum number of poor people and bring them out of poverty. Welfarist theorize that taxpayers' money could be used to meet political and social obligations. However, it can be argued that benefitting a section of the society with the money provided by another section of the society is mere transfer of wealth and no real development is being made. Studies have supported both the schools of thought with their respective limitations.

The institutionalist model has been developed by a group of researchers of Rural Finance Program at Ohio State University. Since then 1980s, this model has grown and taken a strong position in the field of microfinance (Brau \& Woller, 2004; Zeller \& Meyer, 2002). This model emphasized that microfinance institution must achieve self-sufficiency financially to provide and continue their services to the poor. Institution's operation should be independent of free lunch like donation or subsidy rather they should be self-financed to gain long-term viability. Morduch (2000) emphasized that Microfinance institution needed to earn profit as prime objective for achieving self-sufficiency through serving the maximum number of borrowers ranging from poorest to not so poor. Only serving the poorest would incur the highest transaction costs that could be offset by lending not-so-poor borrowers.

According to welfarist, subsidizing microfinance is not a wrong decision as far as the objective has been served appropriately. Besides financial return, the welfarist emphasize on social return of the investment. Microfinance institution can accomplish social sustainability even without accomplishing financial sustainability. Welfarist also does take the view that the poorest people will not be served if institution only gives attention to financial feasibility. They emphasized that serving to the poor by depth (To reach the poorest) and breadth (To maximize numbers) should be the ambit of microfinance institution not achieving self-sufficiency. Woller, Dunford, and Woodworth (1999) stated that microfinance institution objective is rather important than financial solvency. With respect to them, microfinance institution will not be called as subsidized institution if social return exceeds alternative returns and vice versa. The investor in microfinance institution could discontinue investment only when social return falls short, not necessarily financial return. Furthermore, Woller et al. (1999) described that there are two major types of investors in microfinance, namely social investors and selfish investors. Social investors only ask for social development of the borrowers and get them out of poverty. There are two groups in social investors. One group solely happy with poverty alleviation but the other group wants both poverty alleviation and financial sufficiency. However, the extreme selfish investors only seek for maximization of profit out of their investments.

The transformation of microfinance institutions into commercial banks has brought a paradigm shift in their service models, clientele and scope of work. The Institutionalists opine that service recipients must not be the poorest, but a little above the poverty line, to ensure profitability and sustainability of lenders. Rajdev and Bhatt (2013) initial study indicated that microfinance institutions with a profit motivation had a higher chance of sustaining their business. Yet, their latter study indicated that there is insignificant difference for profit oriented microfinance institutions and their counterpart. Overall, their study does not provide conclusive evidence on whether profit motivated microfinance institutions had a higher chance of sustainability. In addition, financial statement analyses done by them indicated that ratios of profit-motivated institutions showed a declining trend. To be specific, ROA (Return on Assets) and ROE (Return on Equity) of profit oriented microfinance institutions had declined whereas the trend was positive for the non-profit oriented counterparts. Though sustainability could be ensured through leveraging, expense control and efficiency improvement, both profit and non-profit oriented microfinance institutions need to be diligent in credit risk and cost management. It was also noted that there was no need for additional regulations to ensure sustainability as long as microfinance institutions exhibited responsible behavior and adopted self-regulation. However, their earlier concluded profit motivation for financial sustainability but later did not find any significance, which ultimately did not 
produce any conclusion.

Both achieving financial sustainability and social objective of microfinance institutions at the same time have always been a big challenge. Achieving profitability and serving poor people may be balancing the scenario. Bassem (2012) studied to analyze the relationship between profitability and outreach in the North Africa and Middle East within the period of 2008 to 2012. He found that there is a neutral relationship between them. However, when microfinance institutions desire to decrease their portfolio risk, there is a symptom of trade off. Again, a higher portfolio at risk is not related with a low profile client, which does not justify any tradeoff. This means both the objectives are achievable at the same time. Nevertheless, this finding is limited with proxy variables specified for financial sustainability and social outreach.

Initially microfinance institutions are supported by government and donor agency for the welfare of the people. However, subsequently there is a need for self-sustainable model to support for a long period. Day by day, there has been a reduction of government and donor funding. This promotes a lot for the expansion of financially self-sustainable Microfinance Institutions (MFIs) without dependency from outside resources. This development has raised the questions to serve for social performance or financial performance competing with each other. Adhikary and Papachristou (2014) empirically examine to find out this relationship of outreach with financial performance in a panel data from 2003 to 2009 of South Asian countries. Here the methodologies they have used were general method of moments (GMM) estimation and random effects modeling. It has been found that both depth and breadth of outreach are positively correlated with profitability and efficiency but depth in contrast to breadth reduces fund risks. Finally, it is apparent that a financially sustainable microfinance institution may reach its social objective with tolerable risk, because outreach has statistically insignificant negative relationship with financial performance.

Microfinance institutions have mainly three types of business models such as solely profit oriented, without profit oriented microfinance institutions and social profit making entities aiming double bottom line. In compliance with their respective model, they approach for their respective borrowers' together with loan size and pricing. A simple approach can be shown for accommodating vast range of models to predict operational efficiency. Bos and Millone (2015) found that microfinance operating with a high depth of outreach were very efficient. They concluded that higher levels of outreach and profits are possible at the same time. However, their findings contradict previously mentioned other research findings.

In case of North Africa and Middle East area, the correlation between social and financial performance has been a matter of substitution or complimentary. By studying a panel data from 1998 to 2011 with a sample of sixty four microfinance institutions in nine countries and using simultaneous equations, Adair and Berguiga (2014) found that social performance was negatively correlated with financial performance and vice versa. Masood (2013) also found a tradeoff exists in case of India using panel data of fifty five microfinance institutions taking the period from 2005 to 2009. They used the Hausman and Taylor panel data model for their study. The association between financial performance of microfinance institutions with poverty outreach went on opposite direction

Hermes and Lensink (2011) find that there are three stages for drawing conclusions from the lessons on the outreach versus sustainability. Firstly, sustainability compromised with respect to outreach. They found that there was trade-off between those. Therefore, it is not a good idea for mixing microfinance with traditional banking. This gives a useful message for the donors or governments for deciding to fund microfinance by subsidy, donation, grants etc. It is equally important for microfinance practitioners, commercials, academicians and current $\&$ prospective investors for their decisions to upgrade the sustainability of their activities. Secondly, if there could be a relationship between marginal improvements of the financial sustainability with reducing outreach. They hardly found any literature for this type of findings. Finally, further research is to take place in case of this size trade off to draw a convincing conclusion.

There has been a mix reaction in several studies in different period and different parts of the world with different methodology with respect to profitability and outreach of microfinance institutions. Some literatures (Adhikary \& Papachristou, 2014; Bassem, 2012; Bos \& Millone, 2015) say that outreach and profitability can be achieved together, some literatures say (Adair \& Berguiga, 2014; Hermes, Lensink, \& Meesters, 2011; Masood, 2013) that they are negatively correlated where there are need for balancing between them and some (Kipesha \& Zhang, 2013; Rajdev \& Bhatt, 2013) are not conclusive. Therefore, the net consolidation between institutionalist and welfarist stands for ambiguous position. Finally, it matters a little whether the microfinance institution operates in whichever mode, a welfarist or institutionalist irrespective of the investors' desire. The most significant question is whether the microfinance institution and the investor deliver positive outcomes to the poor people lives (Hulme \& Mosley, 1996). 


\subsection{Microfinance Institution Performance}

Microfinance institution will be treated as a good performer if it meets the desired objective or at least in good progress through achieving major part of the objective. Lifting people out of poverty and enhancing their life standards are the main objectives for all microfinance institutions. However, their objectives diverge with respect to perception of investors, borrowers, donors, society and even staffs. When borrowers are benefitted and be able to upgrade their lives with repeated microfinance loan through improving business, good health \& social security, better education \& training etc., they think about the positive contribution and good performance of microfinance institutions. Even society as a whole number of borrowers in a particular area measures microfinance performance through their respective contribution and changes brought forward (Schreiner, 1996).

Schreiner (2003) also pointed out that with reference to investors, as the degree of maximization of profit rises for a particular microfinance institution, it becomes a good performer for higher rate of return on investment. Donors are much more attached with market leverage. It means the share gained by the microfinance institution through reaching maximum outreach to the poor. At this point, the microfinance institution has been considered with higher stability and more efficiency for delivering services to alleviate poverty. However, staff people are very much concerned about their jobs. Their primary thinking is situation of what will happen to them as the donor will leave and stop funding. Therefore, staff emphasizes more on financial sufficiency of respective microfinance institution rather than poverty alleviation. It makes their job secured with sound financial condition of microfinance institute. For them, a good performance comes with good financial sufficiency.

According to Zeller and Meyer (2002), microfinance programs performance could be measured through three phases. The most important phase starts with funding the institution for establishment and then goes for subsidized credit policy. In this phase, the institution performance has been measured though the number of borrowers given loan not though the financial outcome of the operation. It matches with the view of welfarist that claims there is no wrong of giving subsidy to the microfinance institution as long as the poverty alleviation objective is served. In other words, social performance is rather important than financial performance (Morduch, 2000). Particularly, things went wrong during the 1980s. There were many evidence documented that subsidized microfinance institution did not show performance and they were some sort of failed program. The situations got worsen and produced the question of financial sustainability. At larger scale, there developed the institutionalist view. They argued that microfinance institution should attain sustainability to serve the poor at long time through different devices like higher interest rate etc. Here came the good performer would be good financial sustainability holder rather social objective holder (Morduch, 2000; Waller \& Woodworth, 2001).

Zeller and Meyer (2002) pointed out three significant criteria that are very much required to measure the performance of microfinance institute. These criteria are given as Outreach to the poor by length and breadth, Financial sustainability \& solvency and Impact on welfare \& wellbeing of the borrowers. These three criteria should be taken into account in gauging the performance of microfinance institution. Achieving these three criteria simultaneously is quite challenging. However, it will provide the best performer record for the microfinance institute. According to Zeller and Meyer (2002), this is called microfinance triangle. How well a microfinance institute achieves these criteria simultaneous is represented by the Triangle's inner circle. This is the result of institutional innovation through good policymaking, high technology adoption, better organizing capability and efficient $\&$ effective management. However, there may have some balancing in meeting those objectives together. One objective may have to be sacrificed at the cost of other. This is quite often known as mission drift or trade off among these objectives. Hartarska (2005), Zeller and Meyer (2002) and Park and Ren (2001) concluded that in many cases it had not been possible to attain sustainability and outreach to the poor simultaneously for microfinance institution.

Achieving all the objectives simultaneously in a win-win position is not practical as per Hartarska (2005). Park and Ren (2001) found that reaching the poorest will cause low interest rate charge for but high transaction cost for microfinance institute. The poor cannot bear the high interest charge and microfinance institute cannot bear the high transaction costs. Somewhere three needs a balancing between them. One option can be like this that microfinance institute outreaches to the maximum poor with low interest rate and high transaction cost with being dependent of grants and subsidies. The other option can be like that microfinance institute serves not-so-poor people with high interest rate and low transaction cost with being independent of grants and subsidy.

\subsection{Measurement Perspective}

By the term outreach, it means how close the poor people are being served for their well-being. For example, the number of poor, the magnitude of poverty, the variety of services etc. The more indicators with higher index achieved by the microfinance institute, the more it is considered reaching the outreach. Navajas, Schreiner, Meyer, 
Gonzalez-Vega, and Rodriguez-Meza (2000) pointed out six dimensions such as Breadth (Number of credit and Number of accounts), Depth (Mean loan size, Female borrower percentage, Rural borrower percentage, Borrower education level, Ethnicity and Housing type), Length (Financial self-sufficiency, Operational self-sufficiency, Return on asset, Mean loan size to GNP per capita, Portfolio growth, Capital cost to asset, Labor cost to asset, Loan to asset, Donation to loan and Loan size), Scope (Loan, Saving, Insurance and Others), Cost (Price cost and Transaction cost) and Worth (Profit increment and Dropout rate) for measuring outreach.

The study done by Navajas et al. (2000) in the third dimension (Length) of their study was further expanded by other researchers. Much more details study by Cull, Demirguç-Kunt, and Morduch (2007), Gutierrez-Nieto, Serrano-Cinca, and Molinero (2007) and Tucker (2001) figured out some more relevant ratios to measure financial performance. Those ratios or indicators with others are Return on asset, Return on equity, Operational self-sufficiency, Portfolio at risk, Provision expense ratio, Risk coverage ratio, Write-off ratio, Operating expense ratio, Cost per client, Personnel productivity, Credit officer productivity, Funding expense ratio, Cost of funds ratio, Loan loss reserves etc.

\section{Methodology}

Bangladesh has been considered as pioneer in microfinance. By this time, over 33 million of clients are being served with various financial and non-financial services by over 700 registered microfinance institute in Bangladesh. This study intent to measure the social outreach versus financial sustainability of microfinance institute in Bangladesh through panel data analysis. To do this, we have analyzed the relationship between financial performance and depth of outreach of 20 top microfinance institutes of Bangladesh from 2015 to 2017. Top 20 microfinance institutes have been listed by the Microfinance Regulatory Authority (MRA) that gives license to open and practice microfinance in Bangladesh (MRA, 2019). The microfinance institute data are collected from the report published by MRA that also promotes and monitors microfinance sector in Bangladesh. Data have been processed using STATA for this study. The top 20 microfinance institutes in Bangladesh are 1. BRAC 2. ASA 3. Buro Bangladesh 4. TMSS 5. Society for Social Service (SSS) 6. Jagorani Chakra Foundation 7. UDDIPAN 8. Padakkhep Manabik Unnayan Kendra 9. Sajida Foundation, 10. Shakti Foundation for Disadvantaged Women 11. Palli Mongal Karmosuchi 12. RDRS Bangladesh 13. Centre for Development Innovation and Practices 14. Bangladesh Extension Education Service (BEES) 15. Dushtha Shasthya Kendra (DSK) 16. Rural Reconstruction Foundation 17. Manabik Shahajya Sangstha 18. Chiristian Service Society (CSS) 19. Resource Integration Centre (RIC) 20. Gram Unnayan Karma1 (GUK).

\subsection{Measurement Indicators}

Social performance emphasizes on reaching out to maximum number of poor people to bring them out of poverty. Taxpayer money could be used to meet social and political obligation to the society. However, it can be argued that benefitting a section of the society with the money provided by another section of the society is merely transfer of wealth where no real development is being made. Financial performance ensures sustainability of microfinance institution by profit maximization like other business with compromising social performance.

Social performance indicators: The social/outreach performance indicator can be number of borrowers and amount of loan outstanding. It is important to consider borrowers number when emphasizing on depth of outreach. Number of borrowers and amount of loan outstanding at the end of each financial year have been used as proxies for depth of outreach in line with Microfinance Regulatory Authority in Bangladesh.

- Number of Borrowers (NOB) reflects institution's active borrowers at the end of each financial year.

- Loan Outstanding (LO) reflects institution's loan balance at the end of each financial year.

Financial performance indicators: It can be typical three financial variables as has been used as usual in banks \& commercial enterprise and also in line with Microfinance Regulatory Authority in Bangladesh. Those are:

- Return on Assets (ROA) reflecting institution's capability to utilize its assets efficiently and effectively for particular financial year.

- Operating Self-Sufficiency (OSS) reflecting institution's ability to cover all incurred cost for particular financial year.

- Operating Margin (OM) measuring margin produced after deducting all the expenditure for particular financial year.

A microfinance institution has been considered as sustainable and profitable if it can produce favorable ROA, OSS and OM. It has been considered having favorable OSS if it can cover 100\% expenses it has incurred. Higher values of these indicators refer to more efficiency for the microfinance institution. 
Through performing multiple regression analysis, it is to check whether there is a link (positive, neutral or negative) existing between financial performance and social performance for microfinance institution. It will show presence or absence of trade-off between these two performances. With reference to Trebucq and d'Arcimoles (2002), there are two hypotheses while assuming presence of relationship between financial and social performance. The first one is with reference to "Slack Resources Theory" stating positive / favorable impact of good financial performance on social performance of an entity.

\section{$\mathrm{H}_{0}$ : Higher Financial Performance leads to higher Outreach with other conditions remaining the same.}

Here, Dependent variable is Outreach (OUTREACH) with indicators like Number of Borrowers (NOB) and Loan Outstanding (LO). Independent variable is Financial Performance (FP) with indicators like Return on asset (ROA), Operating Self-Sufficiency (OSS) and Operating Margin (OM). The econometric model corresponding to this analysis where $\mathrm{t}=2015,2016$ and 2017 and $\mathrm{i}=1$ to 20 has been expressed as below:

$$
\text { OUTREACH }_{\mathrm{t}, \mathrm{i}}=\int\left(\mathrm{FP}_{\mathrm{t}, \mathrm{i}}\right)
$$

Where,

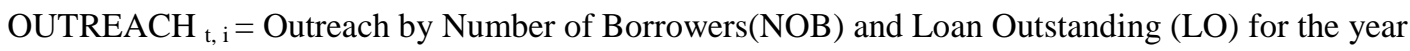

$\mathrm{FP}_{\mathrm{t}, \mathrm{i}}=$ Financial Performance by Return on Asset (ROA), Operational Self-Sufficiency (OSS) and Operating Margin $(\mathrm{OM})$ for the year

The second hypothesis will be formulated with reference to "Good Management Theory" stating positive impact of good social performance on the financial performance of an entity.

\section{$\mathrm{H}_{0}$ : Higher Outreach leads to higher Financial Performance with other conditions remaining the same.}

Here, Dependent variable is Financial Performance (FP) with indicator like Return on Asset (ROA), Operating Self-Sufficiency (OSS) and Operating Margin (OM). Independent variable is Outreach Performance (OUTREACH) with indicators like Number of Borrowers and Loan Outstanding (LO). The econometric model corresponding to our analysis with $\mathrm{t}=2015,2016$ and 2017 and $\mathrm{i}=1$ to 20 has been expressed as below:

$$
\mathrm{FP}_{\mathrm{t}, \mathrm{i}}=\int\left(\text { OUTREACH }_{\mathrm{t}, \mathrm{i}}\right)
$$

Where,

$\mathrm{FP}_{\mathrm{t}, \mathrm{i}}=$ Financial Performance by Return on Asset (ROA), Operating Self-Sufficiency (OSS) and Operating Margin $(\mathrm{OM})$ for the year

OUTREACH $_{\mathrm{t}}, \mathrm{i}=$ Outreach by Number of Borrowers(NOB) and Loan Outstanding (LO) for the year

\section{Analysis and Interpretation}

Social and Financial Performance: Table 1 shows descriptive statistics of different indicators used in this research such as the Outreach indicators (NOB and LO) and Financial indicators (ROA, OSS and OM).

Table 1. Descriptive statistics

\begin{tabular}{lllllll}
\hline \multicolumn{1}{c}{ Indicators } & Definition & Abbre. & Mean & S.D & Min & Max \\
\hline $\begin{array}{l}\text { Number of } \\
\text { Borrowers }\end{array}$ & $\begin{array}{l}\text { Number of borrowers } \\
\text { of respective } \\
\text { microfinance institute } \\
\text { at the end of each } \\
\text { financial year }\end{array}$ & & & & & \\
& NOB & 835826 & 1640166 & 123079 & 6794853 \\
\hline $\begin{array}{l}\text { Loan } \\
\text { Outstanding }\end{array}$ & $\begin{array}{l}\text { Amount of loan } \\
\text { outstanding at the end } \\
\text { of each financial year } \\
\text { of respective } \\
\text { microfinance institute } \\
\text { (Million \$) }\end{array}$ & & 215.69 & 436.20 & 25.38 & 1829.19 \\
\hline $\begin{array}{l}\text { Return on } \\
\text { Asset }\end{array}$ & $\begin{array}{l}\text { Net operating } \\
\text { income/Average total } \\
\text { assets }\end{array}$ & ROA & 3.88 & 3.34 & 0.03 & 11.54 \\
\hline Operating & Financial revenue/ & OSS & 89.73 & 66.29 & 0.03 & 182.48 \\
\hline
\end{tabular}




\begin{tabular}{|c|c|c|c|c|c|c|}
\hline $\begin{array}{l}\text { Self-Sufficien } \\
\text { cy }\end{array}$ & $\begin{array}{l}\text { (Financial expense + } \\
\text { Net loan loss } \\
\text { provision expense } \\
+ \text { Operating expense) }\end{array}$ & & & & & \\
\hline $\begin{array}{l}\text { Operating } \\
\text { Margin }\end{array}$ & $\begin{array}{l}\text { Operating margin } \\
\text { after deducting all the } \\
\text { expenses/ Financial } \\
\text { revenue }\end{array}$ & $\mathrm{OM}$ & 11.11 & 14.21 & 0.04 & 51.95 \\
\hline
\end{tabular}

Before proceeding with the regression analysis, we calculate the correlation coefficients to give us a first look at the relationship that may exist between our indicators (Please see Table 2).

Table 2. Correlation matrix

\begin{tabular}{llllll}
\hline & NOB & LO & ROA & OSS & OM \\
\hline NOB & 1.00 & & & & \\
LO & $0.9821^{* * *}$ & 1.00 & & & \\
ROA & $0.3224^{* *}$ & $0.3783^{* * *}$ & 1.00 & & \\
OSS & 0.1792 & 0.2366 & $0.9001^{* * *}$ & 1.00 & \\
OM & 0.1806 & 0.2509 & $0.6299^{* * *}$ & $0.6132^{* * *}$ & 1.00 \\
\hline
\end{tabular}

*Significant at $10 \%$ level, ** Significant at 5\% level, *** Significant at $1 \%$ level.

The two-outreach variables, NOB and LO have been positively correlated (0.9821) with high relationship at $1 \%$ level of significance. Obviously, higher association between NOB and LO indicates more outstanding loan with more number of the borrowers. Among financial performance indicators ROA, OSS and OM are also highly positively correlated at $10 \%$ level of significance. Hence, it justifies that usually more return on asset will bring more operating self-sufficiency and margin. Number of borrowers has been associated moderately with ROA but not with OSS and OM. Same has been held for LO with OSS and OM. It means only outreach has only effect on microfinance institutes' rerun on asset only. Therefore, it gives us the insight that serving more number of borrowers with more amount of loan makes the microfinance institution only earing some return on assets but not ant other aspects. This is initial indication of no mission drift between social and financial performance.

The purpose of the regression analysis is to detect the existence and magnitude of the relationship between the financial performance and the depth of outreach. This will allow us to determine the mutual impact of these concepts and whether microfinance institutes face trade-off or not, between providing services to the borrowers and achieving financial sustainability. While testing our first hypothesis, we obtain the results presented in Table 3 . All models are estimated by generalized least squares (GLS) rather than ordinary least squares (OLS) since we have included panel data in our models.

Table 3. Regression with outreach indicators as dependent variables

\begin{tabular}{lcrrr}
\hline & NOB & & LO \\
\hline ROA & Coefficient & Sig. & Coefficient & Sig. \\
OSS & 26650.83 & 0.178 & 16.34 & 0.164 \\
OM & -0.457 .21 & 0.610 & -0.33 & 0.529 \\
CONS & $3457.03^{*}$ & 0.089 & $2.78^{* *}$ & 0.022 \\
Prob>Chi2 & $734897.80^{* *}$ & 0.026 & $151.47^{*}$ & 0.079 \\
$\mathbf{R}^{2}$ & 0.0006 & & 0.0001 & \\
\hline
\end{tabular}

$*$ Significant at $10 \%$ level, ** Significant at 5\% level, *** Significant at $1 \%$ level. 
While using the number of borrowers as an indicator of the depth of outreach, we use GLM random effects model as per Hausman Test $(\mathrm{Prob}>\mathrm{Chi} 2=0.9769)$. Furthermore, for testing the significance of this model, we find the P-value (Prob> chi2) is 0.0006 which is less than 0.0500 , the significance level chosen in this case. Therefore, the model is significant overall and we reject our null hypothesis (Please see Table 3). The impact of financial performance on the outreach is positive and statistically significant for operating margin indicator only and we do not find any other significant coefficients that can be attested. We can conclude that there is significant relationship between social and financial performance for at least operating margin. The microfinance institute can serve higher number of borrowers with higher operating margin. There is no mission drift for social and financial performance.

In the same way, while using the loan outstanding as an indicator of the depth of outreach, we use GLM random effects model as per Hausman Test (Prob>Chi2 $=0.7364$ ). Furthermore, for testing the significance of this model we find the P-value (Prob> chi2) is 0.0001 which is less than 0.0500 , the significance level chosen in this case. Therefore, the model is significant overall and we reject our null hypothesis (Please see Table 3). The impact of financial performance on the outreach is positive and statistically significant for operating margin indicator only and we do not find any other significant coefficients that can be attested. We can conclude that there is significant relationship between social and financial performance for at least operating margin. The microfinance institute can serve higher amount of loan with higher operating margin. Again, there is no mission drift for social and financial performance.

While testing our second hypothesis, we obtain the results presented in Table 4. Again, all models are estimated by generalized least squares (GLS) rather than ordinary least squares (OLS) since we have included panel data in our models.

Table 4. Regression with financial performance as dependent variables

\begin{tabular}{lcccrrr}
\hline \multicolumn{1}{c}{ ROA } & \multicolumn{3}{c}{ OSS } & OM \\
\hline NOB & Coefficient & Sig. & Coefficient & Sig. & Coefficient & Sig. \\
LO & $0.00^{* *}$ & 0.026 & 0.00 & 0.815 & -0.00 & 0.155 \\
CONS & $0.01^{* * *}$ & 0.005 & 0.22 & 0.588 & $0.19^{* *}$ & 0.019 \\
Prob>Chi2 & $3.36^{* * *}$ & 0.000 & -10.23 & 0.938 & 29.41 & 0.255 \\
$\mathbf{R}^{2}$ & 0.0005 & & 0.0074 & & 0.0002 \\
\end{tabular}

*Significant at $10 \%$ level, ** Significant at 5\% level, *** Significant at $1 \%$ level.

While using the return on asset as an indicator of financial performance, we use GLM random effects model as per Hausman Test $(\mathrm{Prob}>\mathrm{Chi} 2=0.0596)$. Furthermore, for testing the significance of this model, we find the P-value (Prob> chi2) is 0.0005 which is less than 0.0500 , the significance level chosen in this case. Therefore, the model is significant overall and we reject our null hypothesis (Please see Table 4). The impact of social performance on the financial performance is positive and statistically significant for both number of borrowers and loan outstanding. We can conclude that there is significant relationship between financial and social performance. The microfinance institute can attain higher return on asset with higher number of borrowers and loan outstanding. There is no mission drift for financial and social performance.

Again, while using the operating self-sufficiency as an indicator of financial performance, we use GLM random effects model as per Hausman Test (Prob $>$ Chi2 $=0.1135$ ). Furthermore, for testing the significance of this model, we find the P-value (Prob> chi2) is 0.0074 which is less than 0.0500 , the significance level chosen in this case. Therefore, the model is significant overall and we reject our null hypothesis (Please see Table 4). The impact of social performance on the financial performance is not statistically significant for both number of borrowers and loan outstanding. We can conclude that there is neutral relationship between financial and social performance. The microfinance institute is indifferent in this case and also showing no mission drift.

While using the operating margin as an indicator of financial performance, we use GLM fixed effects model as per Hausman Test (Prob>Chi $2=0.0055)$. Furthermore, for testing the significance of this model, we find the P-value (Prob> chi2) is 0.0002 which is less than 0.0500 , the significance level chosen in this case. Therefore, the model is significant overall and we reject our null hypothesis (Please see Table 4). The impact of social performance on the 
financial performance is positive and statistically significant for loan outstanding only. We can conclude that there is significant relationship between financial and social performance for at least operating margin. The microfinance institute can attain higher operating margin with higher amount of loan outstanding. There is no mission drift for financial and social performance.

\section{Summary and Conclusion}

The impact of operating margin on number of borrowers and loan outstanding is positive and statistically significant. We can conclude that there is significant relationship between social and financial performance for at least operating margin. Sorooshian and Dodangeh (2013) defined financial performance as a vital aspect of performance measurements. The microfinance institute can serve higher number of borrowers and higher amount of loan with higher operating margin. The impact of number of borrowers and loan outstanding on return on asset is positive and statistically significant. But the impact of number of borrowers and loan outstanding on operational self-sufficiency is statistically insignificant. Again, only the impact of loan outstanding on operating margin is positive and statistically significant. We can conclude that there is significant or some cases neutral relationship between financial and social performance. Finally, there is no mission drift for social and financial performance as no statistically significant negative coefficients. Therefore, microfinance institute can achieve both the objectives simultaneously in case of Bangladesh.

\section{Acknowledgement}

The authors are grateful to Universiti Malaysia Pahang and Ministry of Education Malaysia for supporting this research through Fundamental Research Grant Scheme (FRGS), grant number FRGS/1/2018/SS01/UMP/02/1 RDU 190168

\section{References}

Adair, P., \& Berguiga, I. (2014). How do social and financial performance of microfinance institutions interact? . A panel data study upon the MENA region (1998-2011).

Adhikary, S., \& Papachristou, G. (2014). Is there a trade-off between financial performance and outreach in South Asian microfinance institutions?. The Journal of Developing Areas, 381-402.

Bassem, B. S. (2012). Social and financial performance of microfinance institutions: Is there a trade-off?. Journal of Economics and International Finance, 4(4), 92-100.

Bos, J. W., \& Millone, M. (2015). Practice what you preach: Microfinance business models and operational efficiency. World Development, 70, 28-42.

Brau, J. C., \& Woller, G. M. (2004). Microfinance: A comprehensive review of the existing literature. The Journal of Entrepreneurial Finance, 9(1), 1-28.

Cull, R., Demirguç-Kunt, A., \& Morduch, J. (2007). Financial performance and outreach: A global analysis of leading microbanks. The Economic Journal, 117(517), F107-F133.

De Briey, V. (2005). Plein feu sur la microfinance en 2005. Regards économiques, 28(1), 1-14.

Gutierrez-Nieto, B., Serrano-Cinca, C., \& Molinero, C. M. (2007). Microfinance institutions and efficiency. Omega, 35(2), 131-142.

Hamed, Y. (2004). Microcrédit et fiancement de la microentreprise au Maghreb. ANRT.

Hartarska, V. (2005). Governance and performance of microfinance institutions in Central and Eastern Europe and the newly independent states. World Development, 33(10), 1627-1643.

Hermes, N., \& Lensink, R. (2011). Microfinance: its impact, outreach, and sustainability. World Development, 39(6), $875-881$.

Hermes, N., Lensink, R., \& Meesters, A. (2011). Outreach and efficiency of microfinance institutions. World Development, 39(6), 938-948.

Hulme, D., \& Mosley, P. (1996). Finance against poverty (Vol. 1). London: Routledge.

Kipesha, E. F., \& Zhang, X. (2013). Sustainability, profitability and outreach tradeoffs: evidences from microfinance institutions in East Africa. European Journal of Business and Management, 5(8).

Masood, T. (2013). Trade-Off between Financial Performance and Poverty Outreach-Evidences from Panel of Indian Microfinance Institutions. 
Morduch, J. (2000). The microfinance schism. World Development, 28(4), 617-629.

MRA. (2019). Microcredit Regulatory Authority. Retrieved from http://www.mra.gov.bd

Navajas, S., Schreiner, M., Meyer, R. L., Gonzalez-Vega, C., \& Rodriguez-Meza, J. (2000). Microcredit and the Poorest of the Poor: Theory and Evidence from Bolivia. World Development, 28(2), 333-346.

Park, A., \& Ren, C. (2001). Microfinance with Chinese characteristics. World Development, 29(1), 39-62.

Rajdev, A., \& Bhatt, K. (2013). An Analysis of Sustainability of Microfinance Institutions \& its Determinants: Using Institutionalist Approach. Conference: Value Creation for Sustainable Growth in 21st Century At: Ganpat University, Mehsana, Gujarat. Retrieved from https://www.researchgate.net/publication/299512526

Schreiner, M. (1996). Thinking about the performance and sustainability of microfinance organizations. Unpublished paper, The Ohio State University.

Schreiner, M. (2003). The Performance of Subsidized Microfinance Organizations: BancoSol of Bolivia and the Grameen Bank of Bangladesh: Edwin Mellen Press.

Sorooshian, S., \& Dodangeh, J. (2014). Modeling on performance drivers of project management. Advances in Environmental Biology, 7(13), 3890-3894.

Trebucq, S., \& d'Arcimoles, C.-H. (2002). The corporate social performance-financial performance link: evidence from France. Univ. of Bordeaux Dept. of Int'l Acc'tg Working Paper(02-01).

Tucker, M. (2001). Financial performance of selected microfinance institutions: Benchmarking progress to sustainability. Journal of Microfinance/ESR Review, 3(2), 7.

Von Pischke, J. D., Adams, D., \& Donald, G. (1983). Rural financial markets in developing countries; their use and abuse.

Waller, G. M., \& Woodworth, W. (2001). Microcredit as a grass-roots policy for international development. Policy Studies Journal, 29(2), 267-282.

Woller, Dunford, C., \& Woodworth, W. (1999). Where to microfinance?. International Journal of Economic Development, 1(1), 29-65.

Yaron, J. (1994). What makes rural finance institutions successful?. The World Bank Research Observer, 9(1), 49-70.

Zeller, M., \& Meyer, R. L. (2002). The triangle of microfinance: Financial sustainability, outreach, and impact. Intl Food Policy Res Inst. 